\author{
Kevin Roberts
}

\title{
A Deal with the Devil: Practicalities vs Academic Accommodations in Teaching First Year Poetry Writing at Malaspina University-College
}

\author{
Nor is there singing school but studying \\ Monuments of its own magnificence \\ - W.B.Yeats Sailing to Byzantium \\ Lyf so short, the craft so long to lerne \\ - Geoffrey Chaucer Parlement of Foulys \\ Interviewer: "Do you revise a great deal?" \\ Robert Lowell: "Endlessly." \\ - Writers at Work. Paris Reviews.1963
}

A few years back I did a poetry reading at a greystone New South Wales university. Over the inevitable wine at the faculty bar afterwards I heard for the umpteenth time the hoary statement from my academic host that poetry couldn't be taught - that talent is innate and will inevitably emerge blossoming from its standard starvation garret - that no doubt, as a poet, I agreed, that all these creative writing classes were pointless. And so on. We've all heard it before, certainly from English Departments in Canada. I created a disapproving silence when I ventured that while I had never as a student myself taken a creative writing class I wish I had - that I had wasted many moons writing in blind alleys when so many tricks of the trade were quickly available and teachable. I further stirred the pond by suggesting that many fine books emanated from creative schools, and that creative writing classes, if they did not turn every student into Shakespeare, at least turned students into attentive readers extremely aware and appreciative of well-written work. But the flow of wine dried up completely when I admitted I taught creative writing classes as well as English. It seemed I had gone over to the "dark side".

Ah, well, I'd been there before; though I've never really understood why the seemingly natural combination of reading and writing and teaching still builds such a schism in the study of English. Of course teaching creative writing/poetry rather than the more acceptable journalism or nonfiction brings out the worst of these attitudes and is one of the first accommodations creative writing faculty make with the "devil". English Department scholarly "culture" is another problem. But I should add that the English Department.at Malaspina UniversityCollege (MUC) - at Nanaimo, on Vancouver Island in British Columbia - is an 
anomaly. Of the 30 or more English Faculty, several of them, like myself, teach both English and Creative Writing courses and nearly half have published or support the publication of poetry in contemporary magazines. This makes the position of the MUC Creative Writing Department much easier than in some Canadian universities where a state of war exists between English and CW faculty.

A major accommodation concerns the size of creative writing classes at tertiary level in British Columbia. A series of leisurely sessions with two or three students with no time pressure - a relaxed atmosphere where poetry manuscripts can be exchanged and discussed - would be ideal. Not so. The basic method of teaching creative writing in British Columbia, in Canada and in North America, is the group workshop approach. Derived probably from Iowa University originally, its acceptance is now widespread. Working best with groups of about ten, the exigencies of recent funding cuts to universities requires modifying these courses so that they fit into the larger university pattern of acceptable student/faculty ratios, regardless of whether these increased sizes undermine the effectiveness of the workshop approach or not.

Once a year the British Columbia universities and two-year colleges teaching creative writing meet for "Articulation" - discussions relating to the acceptance of new or changed Creative Writing courses, transfer credits and the general state of Creative Writing in British Columbia. In particular the Articulation Committee examines for approval student transfer credits from two-year colleges to the degree-granting institutions - University of Victoria, University of British Columbia, Malaspina University-College - and general transfer credit acceptance between all the BC Creative Writing institutions. The May 10th minutes of the 2002 Articulation Committee meeting revealed deep concerns over the implications of the new BC Liberal Government's Bill 28 - specifically the demand for higher productivity in all BC tertiary institutions. Expectations are that an unacceptable average $30 \%$ increase will be required in Creative Writing. This factor the Articulation Committee considered threatening to effective pedagogical processes. The "devil" in this case is clearly a Government which demands productivity over the quality of instruction. But this is not new.

Previous British Columbia budget cuts at Malaspina University-College (and other BC universities) recently led us to modify the workshop numbers, trading a vastly enlarged class of 30 in first year for manageable increases in upper division sections. This was as a result of unremitting pressure from other Areas and Deans who demanded their pound of academic flesh be weighed on student contact hours scales. Administrators of courses shrugged at CW complaints and suggested everybody was bleeding. The Creative Writing Department, like any program, had to adjust and accommodate intra-University demands. The small numbers involved in Creative Writing workshops are implicitly vulnerable to mindless bean-counting. Consequently I ended up with a first year CW poetry writing class of 32 at Summer School in $2002-2$ x 3hrs/week for 7 weeks. I had to come up with approaches that maintained the standards for a large number of first years - novice writers involved in a short and intense course. I say "novice" because there is no entrance portfolio submission required for first year $\mathrm{CW}$ as found at the University of British Columbia (UBC - MUC's linked university). At MUC, with heavy demand for Creative Writing courses and hundreds of applications, it would be a gargantuan task. Further, MUC institutional requirements for admission from high school Grade 12 are set for socio/political/community reasons at "C+" (65-70\%) and changing that would require a massive internal struggle. The concept of universal open access to university courses for all is a cherished egalitarian principle at MUC, a throwback to MUC's beginnings as a Community College in the late 60s. Recently, under enrolment pressure, UBC and Simon Fraser University 
increased their admission level for some areas to a Grade 12 "B". However, the MUC mission statement "ethos" maintains, perhaps naively, that very good teaching can improve any student. Hence first year entrance requirements are close to an open-door policy, though this has changed considerably over the years. Still, a CW entrance portfolio would constitute an abrogation of tradition and could require a lengthy debate in one of the sub-committees of the MUC Education Council - MUC's equivalent of a University "Senate".

Content is also an institutional concern. The strong British Columbia Human Rights Commission rules run counter at times to outright free academic expression, and factors like "inclusive language" and ethnic, gender, and racial concerns and guidelines thereto have to be stated very clearly in any course outline to avoid potential complaints. This is one of the most bothering elements of teaching creative writing. A "chill", or implicit "censorship", has snaked in and exists on campus, not clearly related to the outside world of writing and publishing. While it is outside the scope of this article it may suffice to say that the clash of academic freedom ensconced in free speech and constraining Government legislation in Human Rights and other attempts to "protect" citizens from pornography and other social/ethnic/gender "evils" has yet to be resolved. For example, one would be hard-pressed to find many MUC faculty, apart from myself, foolhardy enough to teach Conrad's Heart of Darkness these days because of the attacks on the book by Chinua Achebe and others for Conrad's implicit and overt racism (Kimbrough 1992). Despite the text's clear criticism of Imperialism, Conrad's use of politically incorrect terms and the view of the indigenous Africans as "other" has pushed this book into a dusty academic corner. Further, almost in parallel with Victorian hypocrisy, the unspoken pressure is on faculty to encourage CW students to shy away from topics or language that cross over or enter into awkward or sensitive social zones. Accommodations again.

I think the secret of a successful course with 30 students is time management involving detailed course planning and organisation. Contrary in many ways to the actual creative poetic process which involves ruminating in each of the diverse poetic stomachs, or simply waiting and reflecting, this highly-planned procedure is a necessary accommodation for a successful short course in poetry writing. There is no point at all in simply saying to first years "write a poem". All you'd get would be Hallmark Cards. Most of the students we admit are moderately clueless initially, and have read little poetry. First year CW poetry is a "frontier" introductory course, probably the most challenging course in CW.

Another accommodation I undertook with the "dark side" was to make a false distinction between art and craft, splitting the two initially, then melding them together as the course progressed. The "art" I designated as experiential encounters or exercises intended to shake up, enlarge and re-shape the students' perceptions. Content initially is not a major concern apart from the Human Rights Commission guidelines. In first year I do not set themes or topics, finding that these are too limiting. Instead I rely on developing the students' "new" eyes to see differently. "Craft", I decided, was to come from wide reading and critical examination of a host of poetry from anthologies and literary magazines as well as the students' own workshopped poems at a later date. Hypertext poetry is a possibility in a later senior class, but not in first year, though we do look at "found" and "concrete" texts.

I think that Yeats is correct when he talks in "Sailing to Byzantium" about a "singing school" and the "monuments of its own magnificence". The more poetry a student reads the broader his or her view of poetics will grow. But diversity, I think, is more critical than being overwhelmed by Eliot's sense of "Tradition and the Individual Talent" as expressed in his famous essay from The 
Sacred Wood in 1920. I encourage students to realise that poetry is written in houses close to their own, in villages like Lantzville and Qualicum, not only in New York or London, and that their own experiences are explicitly worthwhile material for poetry. These are important distinctions. It is truism that one learns music/painting, etc. as an "apprentice" by exercise. As Pound suggests in "A Retrospect", a "candidate" for poetry is no different (Pound 1935). However, the initial "spark" can be fostered and the content conceived in a unique way. My $\mathrm{CW}$ plan for the course was that students would be agitated and aroused into an original perception by an exercise and then employ their recently acquired knowledge of poetic craft in the creation of a poetic text. In a primitive, awkward, and even innocent manner this actually happened, but not until the jingle-jangle residue of metered sing-song was examined and put to rest. Much of the initial course focus was on eliminating the doggerel deep in the bones, the patty-cake stuff wormed like couch grass into their inherited "word-hoard". Not that this is a bad thing at all. I emphasise the virtues as well as the potential vices involved. But it's necessary for the students to learn to "see" again and not take the conventional postcard view of life.

Sometimes a small civil war between royalists and rebels breaks out over this matter where form and content are at loggerheads, but I point out several traditional verse templates where words are chosen less for their importance than their syntactical need, where what the poet wants to say may be sometimes diverted by the external needs of form and meter. (A Shakespearean sonnet is useful here.) Not surprisingly, resistance melts when more and more examples of contemporary poetry are examined, and the students' poems written earlier in high school, beloved of teachers and grandmothers, show their artistic poverty. But I think the exercises are where the poetry really begins to emerge. Many of the "games" I use are simple kid's stuff, but mature students find them just as engaging and challenging as the students straight out of Grade 12.

I don't remember whether I've picked up or created the poetic exercises I employ. Certainly some of them are standard fare. My first class exercise involves observation and sight/insight. Asking the students to close their eyes and scribble down answers, I throw out questions about the space they're in - the colours and numbers and shapes and placement of things in the room. After their limited success, I point out how we all walk about like somnambulists hardly noticing the world passing by us, how writers need to be aware of the universe about them. Often I will ask the group to draw a light bulb. The bulk of them will draw a one dimensional, side-on view. I draw on the board the possibility of other views of the light bulb and the idea starts to sink in. I emphasise the importance of observing and remarking upon details. A further discussion ensues concerning the inevitable Euclidean order we exist in - the squares and rectangles and circles of modern buildings - in contrast to the world of nature outside the rectangular windows where Atwood's "ordered absence" exists in all its power (Geddes 491). I further attempt to relate sight to insight, to the way in which details imply larger concerns, to the power of colour, the rainbow, roygbiv, to Blake's conception of the "world in a grain of sand". I urge them to reflect upon the fact that $80 \%$ of the world comes into us through our eyes; that writing, as Conrad says in the preface to The Nigger of the Narcissus (1898) should make the reader "see" and in that "seeing" go beyond sight into insight. Poetically, as W.C. Williams says, there are "no ideas but in things" (Geddes 928); that so much "depends" upon a "red wheelbarrow", upon a simple clear verbal picture realised contextually/dramatically.

One early exercise which works very well is to take a small coloured birthday candle, place it where it's easily visible, darken the room and simply set the candle alight, requiring that the students scribble down their reactions and associations as the tiny flame grows and finally dwindles. This exercise has the 
advantage of flooding each student with memories over a defined time factor and a dramatic context. It's impressive to see the silence which ensues, the feverish scribbling, and the manner in which they will all gather closer in to watch the last guttering struggle of the candle flame. This is often an emotional event for the students and while the usual clichés of birth, life, and death appear in their writing many students branch out into surprising poetic efforts from this experience.

My approach to looking at established poems is practical/writerly - to foster the "practising apprentice" rather than any literary/theoretical context. Perhaps I'm more like a clockmaker opening the back casing to show students how all the cogs and wheels interact rather than assessing the chronometer's accuracy or appearance. My emphasis is upon "how it's made", what poetic "tricks of the trade" can be found in the poems in terms of dramatic situation, lines, image, prosody, voice, and so on. I don't often suggest imitation or recreation as some $\mathrm{CW}$ teachers do, preferring to examine poems to show what poetic devices can be shoved into the students' "toolbox" for later usage. That is not to ignore the theoretical basis of poetry. I send students off to the library to look into Pound, Levertov, Webb, Williams, cummings, Marlatt, Olson - whatever has been said usefully about the writing of poetry - for class discussion.

An anthology textbook is important. There are any number of them about, but I look for one which is international in scope and adventurous in selection - a hard task - and often I fall back on Geddes' Twentieth Century Poetry and Poetics, as much for its poetics as for its poetry selection, supplementing that text with individual poems from poets like Judith Wright, Les Murray, Gwen Harwood, and others. The writerly comments in the back of Geddes' anthology open up discussion and offer advice about actually writing poetry. e.e. cummings is useful initially as a fence and gate buster, as an experimenter with syntax and space and language, though students realise soon enough that verbal pyrotechnics do not always carry "weight", nor are they suitable for every poem.

I request that students keep a journal of their reactions and thoughts, of things noticed and observed, as a growing record or source book. Occasionally I'll hold a short session where students read bits and pieces from their journals. I recommend to them the old saw that "a writer writes" and that daily observations of ideas, fragments, snippets, concepts, and speech build up a rich warehouse of poetic "fuel".

It seems that the better student efforts come from the exercises, from the stimulus provided. I often bring in objects for "blind" handling, asking the students to go beyond "naming" the thing to a sensual appreciation of its qualities and whatever floods into their minds from the experience. Tree leaves, golf balls, pine cones, sea shells, apples, even eggs (a bit dangerous, but exciting) all work well when the students are asked not just to identify but to verbally describe and react to the shapes, textures, and forms and their associations. Music also provides stimulus - Bach, Mahler, and Beethoven in short segments, as does playing a record of Dylan Thomas reading "A Child's Christmas in Wales", where the plethora of sound and image is rich and stimulating. I employ worksheets with beginning words or phrases ready to be expanded upon or developed in various ways. Asking the students to bring in an object each and handing the pieces about (not blindfolded this time) also creates interesting responses. I have sometimes taken the students down to the nearby art gallery, or pinched a painting from the Humanities common room (usually an inventive one) for us to look at and discuss. At the same time the students are reading a wide variety of poems and the mix of "art" and "craft" seems to work well. 
Another exercise, one I use fairly early on, involves two lists on a page, one on the far left and one on the far right, separated by the repeated words in the centre 'is like' to complete a simile when the words are filled in. On the left side of the page I get the students to write down a series of abstractions, one under the next - Anger, Love, Fear, Truth, Power, War, etc. I then ask students to write down the first thing that comes into their heads from an announced list of Animal, Vegetable, Mineral, Fish, Tree, Flower, etc. The results are not always immediately interesting, but something like:

$$
\text { Truth is like an onion }
$$

or

$$
\text { Love is like a rhinoceros }
$$

offer students the possibility of examining and enlarging the concept into a larger text.

More interesting and challenging are combinations which at first do not seem to fit or are contradictory - War is like Gold - or Truth is like a Goldfish - where the students are obliged to ponder the possible implications of such liaisons. I request the students to take at least two, one felicitous, one far less so, and work on enlarging and developing a context, dramatic or verbal where the simile can expand out in some way or other. Of course, not every exercise hits home for every student, but it's surprising to see how many original poems emerge from these "games". I have the suspicion that a lot of writing is just "messing about with words" anyway, and these exercises support that notion. It is not always easy to convince students that a poem in draft is not inviolate, that it can be trampolined and juggled and rearranged. I attempt to break the students' psychological "set" by suggesting that they break the normal expectations of customary linear syntax, jump out of the "box", that they attempt to incorporate the unusual, the irregular, the infraction, the "flying fish" or "platypus" of language so that the serendipitous miracle of a startling image on a line may emerge. Naturally, this does not always produce the desired effect and the bizarre and freakish often surface. But this is better than the ordinary and the mundane and can be worked on. I also suggest to students that they cut their poems up into separate words and "deal" them out like cards to see what emerges. After the students' initial horror that a poem can be thus violated the results are usually interesting and challenging.

Another exercise I use towards the end of the course, when the students have lots of "fuel" in their journals - less successful perhaps in first year but really good later on - is to write a line of poetry / fold it down / pass it on / repeat the process. Students use lines from any poem or journal note. After ten or fifteen attempts at lines written, folded back and passed on, the individual student gets to unfold whatever page he or she ends up with: what appears to be a series of disjointed lines. The effort then is to organize, cut, rewrite and order the lines so that something like a poem appears. This exercise has the value of demanding considerable editorial skills from the students. Other exercises include the "dictionary flip", the "eavesdropping gambit" and the "mystery food" trick. At other times when the snow is flying, the daffodils swaying, or the red leaves falling, I'll simply take the class for a 15-minute campus ramble, journals in hand, to note and record shapes, colours, and anything else. It is useful to suggest to them that they imagine this is the first time they've ever seen a pond or a rhododendron or a crow, that they are explorers or pioneers with a zoom lens camera instead of eyes. 
All this is jolly fun, but poems have to get written so that grades can be assigned, and midterms assessed, so the Dean and the Registrar can sit comfortably in their offices content that a University education is proceeding smoothly and the Devil is not escaping from his cave under the parking lot if the MUC Institutional 'Continuing Assessment' Regulation is breached. To this end I assign a 1000-word essay on Poetics to be handed in at the midterm along with a couple of student poems, revised but still in progress. I require that the essay focuses on what they have read and learned from writers - writerly concepts from, say, Pound, Levertov, Eliot, Rich, Webb and others (Geddes). Further ventures into prosody and theory I leave until senior classes. The students get a full dose of metre/syllabics from later CW courses and particularly from the ubiquitous North American English 200/201 survey of BritLit from Beowulf to Larkin. I look at the midterm essay as an accommodation, as largely a support mechanism for the main aim of the course which is the writing of poetry.

I delay the handing in of the first student poem for at least four weeks until some poetic background has been established and several models and exercises have opened up student perception of just what a poem is or might be. I'm selfish too, in that I do not want to have to deal with old high school stuff that has not emerged from the discussions. Each student brings 30 copies of their original poem to the class. After each poem has been distributed class-wide, every student will then have 30 poems to take home to read and work on. The first group of poems is numbered in class and known as A 1-30. Next, I ask the students to read in turn out loud the poem that falls to them alphabetically. It is impressive how simply listening to a "stranger" read your poem aloud, hesitate here or stumble over line structure or syntax there, can be an educational experience for the writer. At the next class, before we focus on each individual poem, the best process is to put four students together in a group to discuss initial reactions to each poem in turn. This is only after guidelines have been established for approaching each student poem.

I emphasise that the focus here is how to improve the poem - to look at its strengths and weaknesses based on the poetics and techniques already accepted by the class. I ban or attempt to ban knee-jerk reactions such as "I like it/dislike it" on the basis that the reasons behind the like/dislike are the important things to say - that students should dig deeper for their comments. While it may appear that this group idea is the blind leading the blind, it is quite successful on a limited scale as long as the students are prepared and focused on deliberations about initial clarity, structure, lines and images. The guidelines include silence from the poet whose poem is being examined until the discussion is over. I point out that poets are rarely present when an editor reads a submission and the poems themselves have to "grab" attention - that the best or most vociferous argument for your poem in the group means only that you've won an argument probably for an imperfect poem - and the poem should explain itself anyway. At first, the group work may be desultory, and requires a quick whip around to encourage adequate operation. Eventually the initial small group works, because when the individual poem comes up in turn for the larger group discussion I first of all ask the student poet what he or she is going to do to revise it and find most times that the most glaring problems and important elements have already been touched upon. This saves a great deal of whole class workshop time.

There are always the few students who balk or cannot handle comments on their work. I simply point out that if they don't want help they can take their chances with the final grading. I find that these problems dissipate as the course continues and they observe the growth and changes in their peer group. It's also important to point out that rewriting is crucial, that rarely does a successful poem emerge without cuts and editing and sometimes wholesale reworking. Again the essays by poets confirm this endless struggle to complete a poem. 
A major accommodation is the time allotted to individual poems in the whole class workshop. Obviously this is limited - often to a few comments from students and my own quick summary. This is at times a long tedious process where attention can waver when poem after poem comes up for examination, testing my diplomacy. Knowing when to jump in and when to sit back and allow a free flow is critical. Acknowledging and supporting only comments intended to improve the poem is important. I break up the workshop with short exercises or other poems to break the tedium. Again I discourage the like/dislike initial reaction from students, supporting instead whatever thoughtful suggestions come forward concerning editing or technique or structure. An alphabetical list may begin the workshop process, but fairness in "first up" is also important with the second and third student poem. During the examination of the individual poem I require that the student poet sit quietly taking notes. I ask the student after we've looked at her/his poem what has been learnt and what steps may be taken with the rewrite. Of course there is always the mouthy student and the switherer and the mouse that cannot roar, but soon enough the group learns who to listen to and who to disregard. The peer level of appraisal rises slowly but surely, and as the group tunes up, the quality of suggestions improves and the time needed for each poem's appraisal diminishes.

The job of faculty in workshops as judge, adjudicator, referee or just King Solomon is demanding and tiring. However it is always interesting and challenging when the preferences, expectations and, yes, my own prejudices are thrown for a loop by the writing of the odd student work which seems to break all the barriers but still succeeds. Anything can surface. This is the good, the bad, and the sometimes ugly aspect of this course. If the first year students' critical faculties and appraisal capacities are enriched in workshops, then the presiding faculty person is also enlarged by the challenge of $30 \times 4$ poems written by 30 diverse poetic perceptions.

The question or criticism of "cloning", of the "standard" CW poem emerging endlessly from CW workshops at university level, always lingers about. Certainly there is a danger of conformity of style but not that of approach, or content, mainly because of the broad scope of the exercises and the individual nature of the responses to, say, the burning candle exercise, where every student has different personal associations with the event. Promoting a wide spectrum of poetic "models" also lessens the tendency for cloned or "group" writing. Curiously, though, Canadian publishers seem now quite keen to get hold of the better students emerging from the University of British Columbia's CW graduate program. But that is a far cry from first year poetry writing.

Working on the principle that it is better to get students to write and rewrite three or five good poems rather than a larger less manageable number, the chance to workshop rewritten poems is included in the workshop process, though the rewritten poems are placed at the end of the list. The portfolio of the final version of the student poems and the reworked poetics essay from the midterm constitute the work submitted for final evaluation, presented as if to a publisher for consideration. Grading is another accommodation with the dark side of the academic world and a CW issue in itself. How can anyone "grade" a poem? While the ramifications of grading poetry are outside the scope of this article, in first year I attempt to take into account just how much work has been done in rewriting and editing the poem/s handed in as a portfolio for final grading. But basically, after some years of teaching CW, it is not hard to make the distinctions between grades - as easy as grading English papers anyway.

Not all these practical and sometimes child-like approaches to writing poetry work, but I have lost count of the number of first year CW poetry students who have come up to me at about mid-semester and announced with innocent 
sincerity: "I didn't know it was this hard to write a good poem!" I do know that the realisation of the effort in art and craft involved in poetry grows steadily with students in each succeeding year of CW workshops. I also do not know if a future Nobel Prize poet will emerge from a lonely garret somewhere beyond any $\mathrm{CW}$ class, or whether they will have taken a degree in CW at a University where a "deal" has been struck with the academic world. But despite all the academic accommodations involved in teaching $\mathrm{CW}$ poetry writing, I do know that many, many students who have taken $\mathrm{CW}$ classes will certainly appreciate the books of poetry which are published, attend poetry readings, and have a life-long appreciation of the tremendous demands of art and craft involved in writing a fine poem.

\section{References}

Chaucer, Geoffrey. The Riverside Chaucer. Ed. Larry Benson. Boston: Houghton Mifflin, 1987. Return to article

Conrad, Joseph. The Works of Joseph Conrad. London: Dent, 1929.

Eliot, T.S. The Sacred Wood. London: Methuen, 1920. Return to article

Geddes, G. 20th Century Poetry and Poetics. 4th Edn. Toronto: OUP, 1996. Return to article

Kimbrough, D, Ed. Heart of Darkness. Norton Critical Edition. New York: Norton, 1992. Return to article

Lowell, Robert, Ed. George Plimpton. Writers at Work. Second Series. Paris Review, 1963. Return to article

Pound, Ezra. Literary Essays of Ezra Pound. London: New Directions, 1954. Return to article

Yeats, William Butler. The Variorum Edition of the Poems of W.B. Yeats. Eds. P Allt and R. Alspach. New York: Macmillan, 1956. Return to article

Kevin Roberts is an Honoured Research Associate Emeritus Professor at Malaspina University-College in Nanaimo on Vancouver Island. He has published 10 books of poetry, 2 books of short stories, plays and a novel. He recently completed his PhD at Griffith University.

\section{TEXT}

Vol 7 No 1 April 2003

http://www.griffith.edu.au/school/art/text/

Editors: Nigel Krauth \& Tess Brady

Text@griffith.edu.au 